\title{
Buffalo River Floatables Control and Continuous Water Quality Monitoring Demonstration Project
}

Kim N. Irvine

A floatables trap was installed at the mouth of a combined sewer outfall in the Buffalo River, NY, to evaluate the utility of this technology in reducing floatables dispersal. In addition to the floatables trap, two Hydrolab Datasondes were installed to demonstrate the importance of a continuous monitoring system in evaluating impacts of combined sewer overflows (CSOs) on receiving water quality. One Datasonde was hung in the river from the floatables trap near the mouth of the outfall and one was attached to an upstream bridge abutment, to represent ambient river conditions. Monitored parameters included dissolved oxygen, $\mathrm{pH}$, conductivity, temperature, and redox.

Floatables were collected successfully over an eight week period that included both dry weather and three CSO events. The dry weather floatables were collected and analyzed as representative of fugitive inputs from the river that were not related to CSO activity. The floatables were sorted into nine categories and the number, mass, and volume in each category were determined. Mean floatables accumulation rates in the trap were significantly greater for CSO periods than dry weather periods. The distribution of floatables, by category, in the sampled CSOs was compared to the distribution for two sewersheds from a study conducted in Newark, New Jersey. The distributions for the two New Jersey sewersheds were similar to each other, but the floatables in Buffalo consisted of more wood and less plastic. The average mass of floatables trapped per 1,000 cubic feet $\left(28.3 \mathrm{~m}^{3}\right)$ of CSO discharge was considerably less for the Buffalo sewershed than the averages for the two New Jersey sewersheds. Low floatables discharge from the Buffalo sewershed, in part, may be due to sewer hoods.

Irvine, K. 2002. "Buffalo River Floatables Control and Continuous Water Quality Monitoring Demonstration Project." Journal of Water Management Modeling R208-10. doi: 10.14796/JWMM.R208-10.

(c) CHI 2002 www.chijournal.org ISSN: 2292-6062 (Formerly in Best modeling practices for Urban Water Systems. ISBN: 0-9683681-6-6) 
In general, the results for parameters measured with the Datasondes were similar to past spot sampling done on the river. Of greatest interest were the results for dissolved oxygen. Classically described dissolved oxygen sags were not observed in the river at the mouth of the outfall during CSO events. In fact, the greatest decreases in dissolved oxygen levels (at both sites) were observed in association with navigational dredging activities, likely due to sediment oxygen demand when sediment was resuspended.

\subsection{Introduction}

Combined sewer systems serve approximately 43 million people in 1100 communities throughout the United States, with most of these systems being located in the northeast and Great Lakes region. Although combined sewer systems, including CSOs, were a standard design practice, there has been increasing scrutiny from the regulatory community and general public regarding the potential impacts that CSOs may have on receiving water body quality. For example, 21 of the 43 Great Lakes Areas of Concern (U.S. and Canadian) have identified CSOs as a potential source of environmental impairment. The cost for a community to abate CSOs can be considerable; the U.S. EPA estimated this cost to be in the order of US\$41.2 billion for the 1100 communities (Water Environment Federation, 1995).

In considering the impacts of CSOs on water quality as well as the financial burden to municipalities, the U.S. EPA first issued its National Combined Sewer Overflow Control Strategy in 1989. This Strategy subsequently was refined through the Combined Sewer Overflow Control Policy of 1994 (40 CFR Part 122). The intent of this Policy was to establish a consistent national approach for controlling CSOs through more effective implementation of the NPDES (National Pollutant Discharge Elimination System) permit program. The major provisions of the Policy are:

CSO permittees should immediately undertake a process to accurately characterize their CSS (combined sewer system) and CSO discharges, demonstrate implementation of minimum technology-based controls identified in the Policy, and develop long-term CSO control plans which evaluate alternatives for attaining compliance with the Clean Water Act, including compliance with water quality standards and protection of designated uses. (Water Environment Federation, 1994)

As part of the Policy, "nine minimum controls" were established. It was envisioned that implementation of these controls would be among the first steps a municipality would take to reduce CSO impacts on receiving water bodies in an effort to achieve the goals of the Clean Water Act. The nine minimum 
controls included "Control of solid and floatable materials in CSOs"; and "Monitoring to effectively characterize CSO impacts and the efficacy of CSO controls". As such, the objectives of this study were threefold:

1. demonstrate the installation and operation of an end-of-pipe boom and trap system for floatables control;

2. quantify floatables discharge to the Buffalo River Area of Concern from a selected sewershed; and

3. demonstrate the utility of a continuous monitoring system (Hydrolab Datasonde) to evaluate the impacts of CSOs on receiving water body quality.

\subsection{Floatables Characterization and Control}

"Floatables" may be defined as buoyant or semi-buoyant materials that float or remain partially submerged when introduced into surface waters (Parsons Engineering Science, Inc., 1995). Newman et al. (2000) noted that beach cleanup projects typically do not include "natural" materials such as twigs and leaves in the collection and characterization of wash-up material. However, such materials are found in CSOs and must be considered in the design and evaluation of floatables control technologies for CSOs (Newman et al., 2000). Natural floatable materials were included in this study.

The U.S. EPA (1995) identified various possible floatables control technologies, including simple baffles, trash racks, static screens, end-of-pipe nets and booms, and skimmer boats. Information regarding the use, cost, and performance of the different technologies is now becoming available (e.g. Parsons Engineering Science, Inc., 1995; Newman et al., 1997; Leo and Kloman, 1997; Cigana et al., 1999; 2000; Shenman, www.trashskimmer.com/ tp_porttech.htm; Couture et al., 2001). The type of technology used to control floatables and the performance of the technology can be affected by a variety of factors, including characteristics of the floatables themselves, in-sewer hydraulic characteristics, and receiving water characteristics. For example, Cigana et al. (2000) reported that the removal efficiency of simple baffles could range between 20 and $80 \%$, depending on the horizontal flow velocity upstream of the baffle. Cigana etal.(1999) experimentally determined the vertical velocity distribution of floatables material from a Montreal CSO and Newman (2001) used these data to develop a simple mathematical approach to calculate baffle removal efficiency. However, Cigana et al. (1999) noted that little data were available on the composition and characteristics of floatables in CSOs. Newman et al. (2000) reviewed available reports that characterized CSO floatables. Data were available for New York City; Newark, NJ; Hartford, CT; Montreal; and 
Melbourne, Australia. It was difficult to compare results between all reports because of a lack of standardization in classifying and subsequently quantifying the floatables material. It appears, however, that the characteristics of floatables material varies considerably for different cities, and given the limited amount of information available in the literature, it is prudent to obtain site-specific data for design of proper floatables control technology.

\subsection{Study Methods}

\subsubsection{Study Sewershed}

The Babcock St. sewershed (Figure 10.1) was selected as the study sewershed for several reasons: the sewershed represents one of the major overflow points to the Buffalo River Area of Concern); several previous studies (e.g. Irvine et al., 1993; Loganathan et al., 1997; Irvine, 1999) have provided a good understanding of sewershed response to rainfall as well as CSO quality; and the sewershed is upstream of most lake-going ship traffic on the Buffalo River, thereby minimizing disruptions to the study due to wake action.

The Babcock St. sewershed is 705 acres ( $286 \mathrm{ha}$ ) in area, with a mixed land use: $20 \%$ heavy industry; $67 \%$ light industry; $2 \%$ commercial; $11 \%$ residential. Flow enters the overflow chamber via a 72 inch $(1.83 \mathrm{~m})$ brick pipe. Flow to the Bird Island Treatment Plant leaves the chamber via a 24 inch $(0.61 \mathrm{~m})$ pipe, while any excess flow overtops the side weir $(16 \mathrm{ft}$ long $\mathrm{x} 66 \mathrm{in}$. high $(4.88 \mathrm{~m} \times 1.68 \mathrm{~m})$ ) and discharges to the Buffalo River.

\subsubsection{Floatables Trap System}

The floatables trap system, as installed at the Babcock St. outfall is shown in Figures $10.2 \mathrm{a}$ and $10.2 \mathrm{~b}$. This trap, known as the Aftrap ${ }^{\mathrm{TM}}$ system, was obtained from Applied Fabric Technologies (Orchard Park, NY). The size of the trap frame and the boom containment area were designed in consultation with Applied Fabric Technologies staff, taking into consideration peak flow velocities both in the river and the overflow, as determined from past studies (Sikka, 1992; Irvine et al., 1993; Loganathan et al., 1997; Irvine, 1999). In this case, the trap frame was $4 \mathrm{ft} \times 6 \mathrm{ft}(1.22 \mathrm{~m} \mathrm{x} 1.83 \mathrm{~m})$ and it was lined with a removable nylon mesh having $3 / 4$ inch $(19 \mathrm{~mm})$ openings. The trap frame can be lifted by a winch to close the front gate, thereby completely enclosing the floatable material within the trap. The trap and boom were secured in place with steel pilings. Collars around the four pilings, together with foam-filled pontoons, enabled the trap to rise and fall with changes in water level. A tidewater slide 


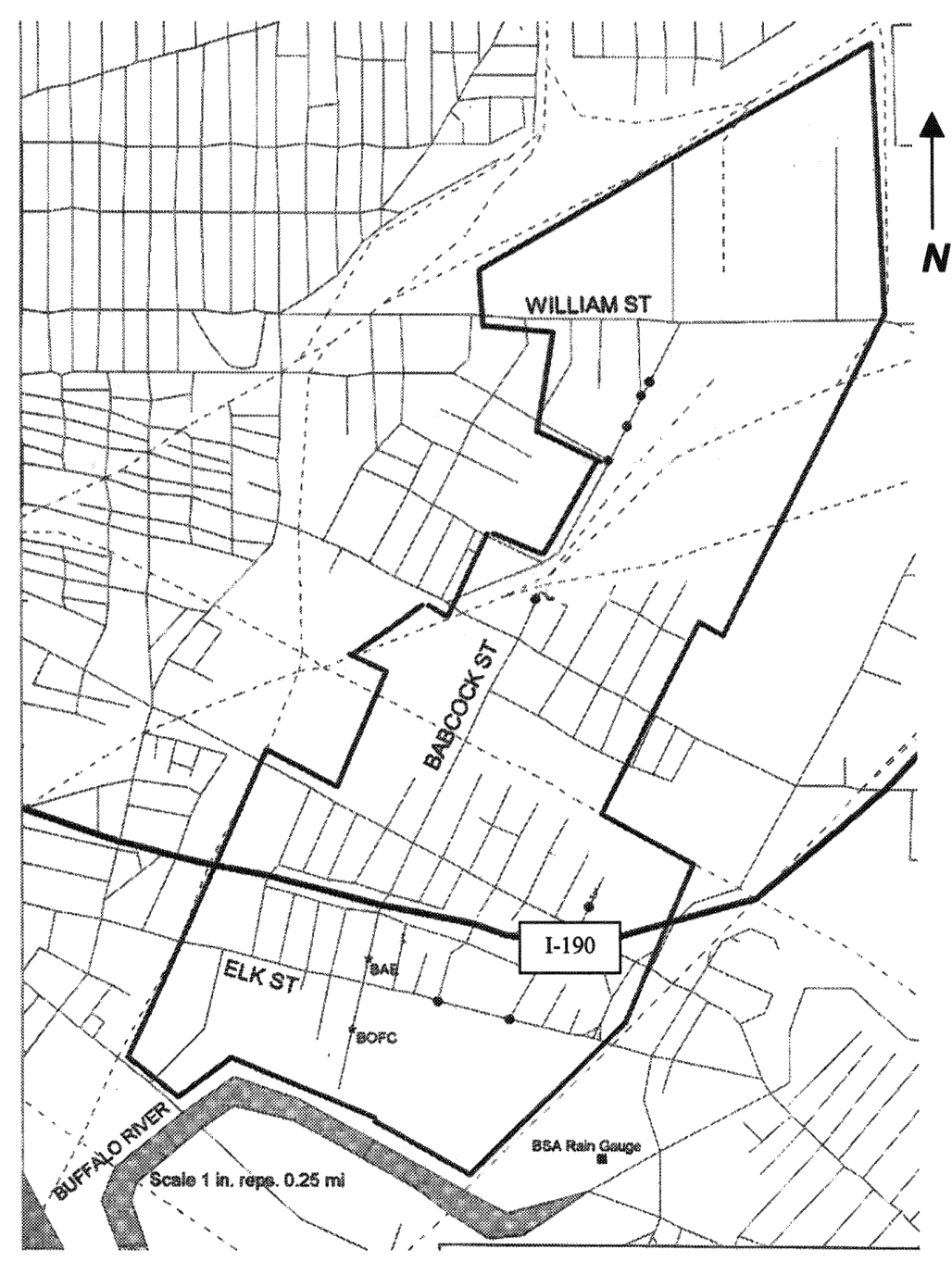

Figure 10.1 Babcock St. sewershed. "BAE" represents the location of the flow meter on the 69 inch $(1.75 \mathrm{~m})$ line north of Elk St., while "BOFC" represents the location of the flow meter in the overflow chamber.

system attached to the pilings enabled the boom to rise and fall with changes in water level.

The floatables were removed for quantification on approximately a weekly schedule, or as soon after a CSO event as possible, between 8/5/99 and 11/5/99. The floatables were placed in garbage containers on a Boston Whaler boat and 

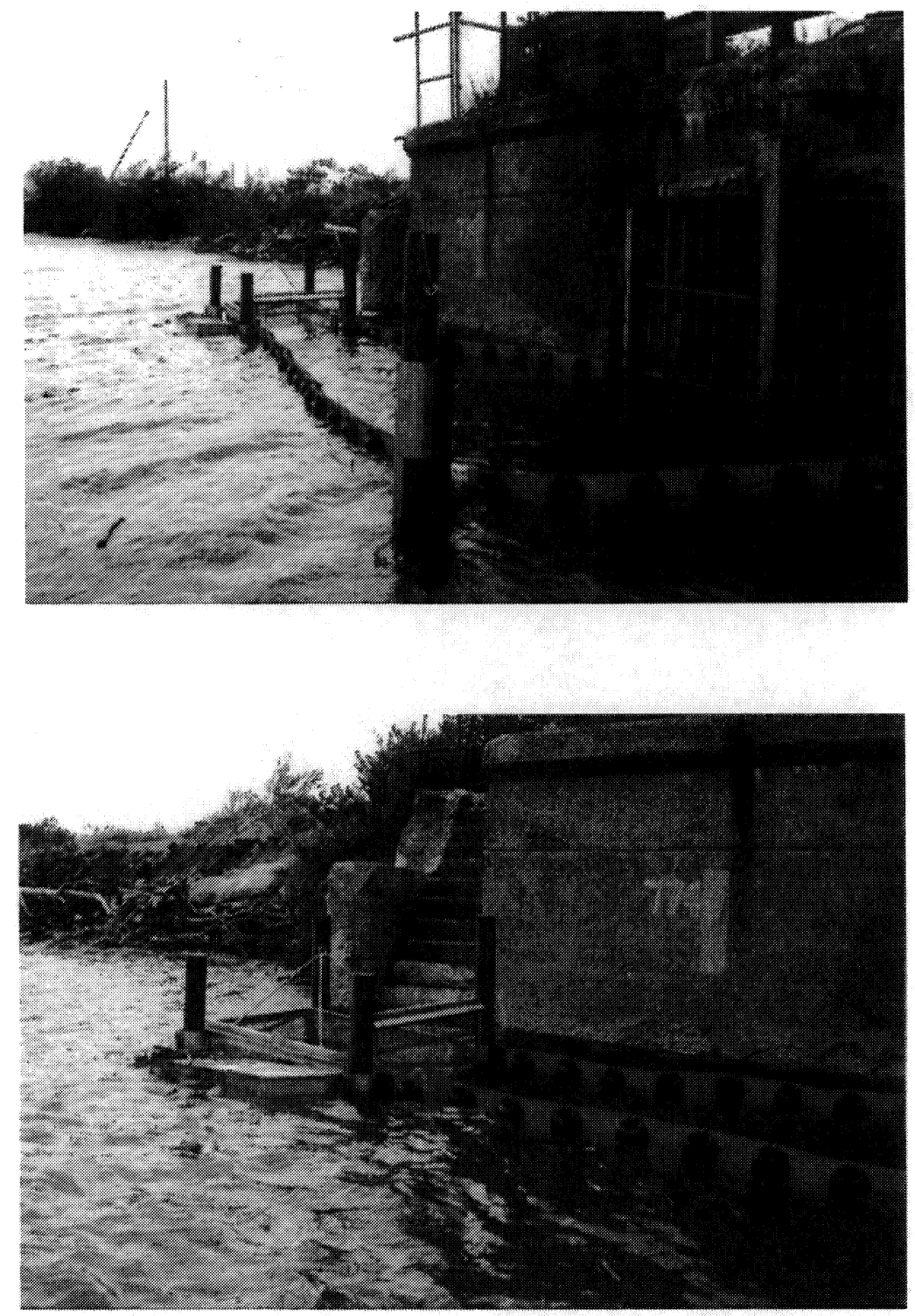

Figure 10.2 (top) Floatables trap at the mouth of the Babcock St. combined sewer outfall. The tidewater slide system is visible on the piling in the foreground. This system enabled the boom to rise and fall with changes in water level. A Datasonde was hung from the boom near the piling in the foreground. (bottom) Close up of galvanized steel frame on pontoons (lined with removable nylon net). 
taken to the Buffalo State Field Station for sorting and analysis. The floatables were sorted according to the material categories used by Parsons Engineering Science, Inc. (1995):

- plastic/paper bags

- plastic bottles

- straws

- other (most commonly other plastics, shoes, condoms, and bottle caps)

- styrofoam

- glass bottles

- wood (includes tree branches)

- medical waste (including syringes and medical vials)

- miscellaneous solids, leaves

The floatables were allowed to dry, sorted by category, counted and then weighed using a hanging balance. Subsequently, the floatables in each category were placed in a calibrated water bath to determine volume.

\subsubsection{Conventional Parameter Monitoring}

One Hydrolab Series 3 DataSonde Multiprobe Logger was installed in the Buffalo River at the mouth of the Babcock outfall by securing it to the floating boom. A second Hydrolab Series 3 DataSonde Multiprobe Logger was anchored approximately $1550 \mathrm{ft}(473 \mathrm{~m})$ upstream on a bridge abutment. The upstream Datasonde provided data on ambient water quality, while the Datasonde at the mouth of the sewer outfall provided data on CSO impacts due to the Babcock St. sewershed. The Datasondes provided a full set of data between $8 / 13$ and 10/29/99 at 15 minute intervals. Measured parameters were dissolved oxygen, $\mathrm{pH}$, temperature, conductivity, and redox (oxygen reduction potential).

Because the Datasonde at the mouth of the CSO was attached to the floating boom system, it took readings consistently at a depth of $4.92 \mathrm{ft}(1.5 \mathrm{~m})$. The Datasonde at the upstream site was installed at a fixed elevation on the bridge abutment and the mean depth of parameter measurement was $3.74 \mathrm{ft}$ $\pm 0.56 \mathrm{ft}(1.14 \mathrm{~m} \pm 0.17 \mathrm{~m})$. The greatest range of depth for parameter measurement within a weekly sampling period at the upstream site was 1.31$6.89 \mathrm{ft}(0.4-2.1 \mathrm{~m})$.

The data for each Datasonde were uploaded to a laptop computer and all sensors were cleaned on the days that the field crew serviced the floatables trap. Dissolved oxygen, $\mathrm{pH}$, and conductivity were calibrated according to Datasonde standard methodology at approximately a two week interval. 


\subsubsection{Flow Monitoring}

Marsh-McBirney Model 370c flow meters were installed at two sites to measure dry and wet weather flow within the sewer system as well as the overflow timing and volume. One meter was installed in the 69 inch $(1.75 \mathrm{~m})$ main line along Babcock St., up-pipe of the overflow chamber, to provide data on both the sanitary (dry) and wet weather flow within the sewer system. The probe for the second meter was installed in the overflow chamber on top of the weir to determine overflow timing and rate (Figure 10.1). Readings were taken every five minutes and the data were uploaded to a laptop once a week.

\subsection{Results}

\subsubsection{Floatables}

Floatables were successfully collected for five dry weather periods and three CSO periods. The dry weather floatables were collected and analyzed as representative of "fugitive inputs" from the river that were not related to CSO activity. There were five sample periods during which the frame of the floatables trap dropped with a reduction of the river level and then became stuck on the piling. As a result, when the river level rose, the trap remained partially submerged and this also partially submerged a section of the boom nearest the trap frame. During these periods of submergence "fugitive inputs" could have occurred and likewise, had there been a CSO, floatables related to the event could have escaped the system. Because of the data uncertainty, these five sample periods were not included in the analysis. Table 10.1 summarizes the floatables data.

The accumulation rates in Table 10.1 are expressed on a standardized "per day" basis because not all sample periods were of the same duration. The "CSO Period" in Table 10.1 includes the inputs from both the overflow event and fugitive inputs from dry weather. The standard deviations in the data were relatively large and the sample size was small, but Student's t-tests indicated that the mean accumulation rates by number of items, volume, and mass were significantly greater for the CSO periods than the dry periods at $\mathrm{p}=0.08, \mathrm{p}=0.15$, and $p=0.11$, respectively. The mass of floatables trapped per 1000 cubic feet $\left(28.3 \mathrm{~m}^{3}\right)$ of CSO discharge for the Babcock sewershed is summarized in Figure 10.3. This mass was adjusted by subtracting the dry period mass for the appropriate number of days in the sample period (the dry period mass calculation was based on the mean dry period accumulation rate of $0.59 \mathrm{lbs}$ $(0.268 \mathrm{~kg})$ per day). Therefore Figure 10.3 represents only the floatables mass 
Table 10.1 Floatables accumulation rate (expressed on a per day basis).

\begin{tabular}{|c|c|c|c|c|}
\hline Sample Period & $\begin{array}{l}\text { Rate by } \\
\text { Number of } \\
\text { Items }\end{array}$ & $\begin{array}{l}\text { Rate by } \\
\text { Volume } \\
\text { (c.c.) }\end{array}$ & $\begin{array}{c}\text { Rate by } \\
\text { Mass } \\
\text { (grams) }\end{array}$ & Comment \\
\hline $8 / 5-8 / 13 / 99$ & 6.9 & 44.1 & 29.6 & Dry Period \\
\hline $8 / 13-8 / 23 / 99$ & 23 & 805 & 572.4 & Dry Period \\
\hline $8 / 23-8 / 27 / 99$ & 86 & 3021 & 2138.0 & CSO Period \\
\hline $8 / 27-9 / 3 / 99$ & 5 & 390.6 & 207.5 & Dry Period \\
\hline 9/3-9/10/99 & 33.8 & 1352.1 & 820.3 & CSO Period \\
\hline 9/10-9/17/99 & 29.6 & 792.3 & 442.5 & Dry Period \\
\hline 9/17-9/24/99 & 0.4 & 185.7 & 88.8 & Dry Period \\
\hline 9/24-10/1/99 & -- & -- & -- & Trap Submerged \\
\hline $10 / 1-10 / 7 / 99$ & -- & - & - & Trap Submerged \\
\hline $10 / 7-10 / 15 / 99$ & -- & - & - & Trap Submerged \\
\hline $10 / 15-10 / 22 / 99$ & -. & -. & -- & Trap Submerged \\
\hline $10 / 22 / 99-10 / 29 / 99$ & -- & -- & -- & Trap Submerged \\
\hline $10 / 29-11 / 5 / 99$ & 160 & 16860.6 & 5632.7 & CSO Period \\
\hline Mean, CSO Period & 93 & 7007.9 & $2863.7(6.3)^{*}$ & \\
\hline S.D., CSO Period & 63 & 8513.1 & $2486.9(5.5)$ & \\
\hline Mean, Dry Period & 13 & 443.5 & $268.2(0.59)$ & \\
\hline S.D., Dry Period & 15 & 346.8 & $232.2(0.51)$ & \\
\hline
\end{tabular}

"bracketed numbers are in lbs; S.D. is standard deviation

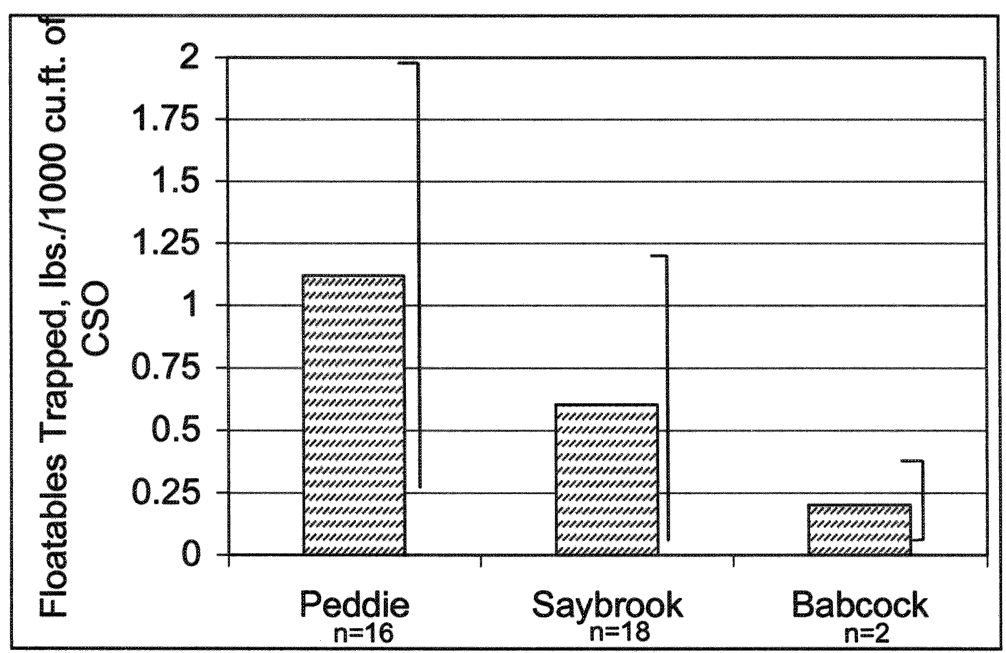

Figure 10.3 Mean floatables discharge rates per 1,000 cubic feet $\left(28.3 \mathrm{~m}^{3}\right)$ of CSO for the Babcock St. sewershed (number of events =2); Peddie sewershed, NJ (number of events = 16); and Saybrook sewershed, NJ (number of events = 18). New Jersey data from Parsons Engineering Science, Inc. (1995). Vertical bars represent \pm one standard deviation. 
due to the CSO. The number of events for the Babcock St. sewershed in Figure 10.3 is two because the flow meter was not operating properly for the sample period 8/23-8/27/99. For comparison purposes, floatables data from two sewersheds in Newark, New Jersey (Parsons Engineering Science, Inc., 1995) also are plotted in Figure 10.3. It should be noted that the trap netting for the New Jersey study was $1 / 2$ inch $(12.7 \mathrm{~mm})$ as compared to $3 / 4$ inch $(19 \mathrm{~mm})$ for this study. Land use in the two New Jersey sewersheds was as follows:

\begin{tabular}{ll}
\hline Peddie Sewershed & Saybrook Sewershed \\
\hline Residential - $63 \%$ & Residential - $16 \%$ \\
Commercial - $8 \%$ & Commercial - 54\% \\
Industrial - $18 \%$ & Industrial - $8 \%$ \\
Recreational - $11 \%$ & Recreational - 22\% \\
\hline
\end{tabular}
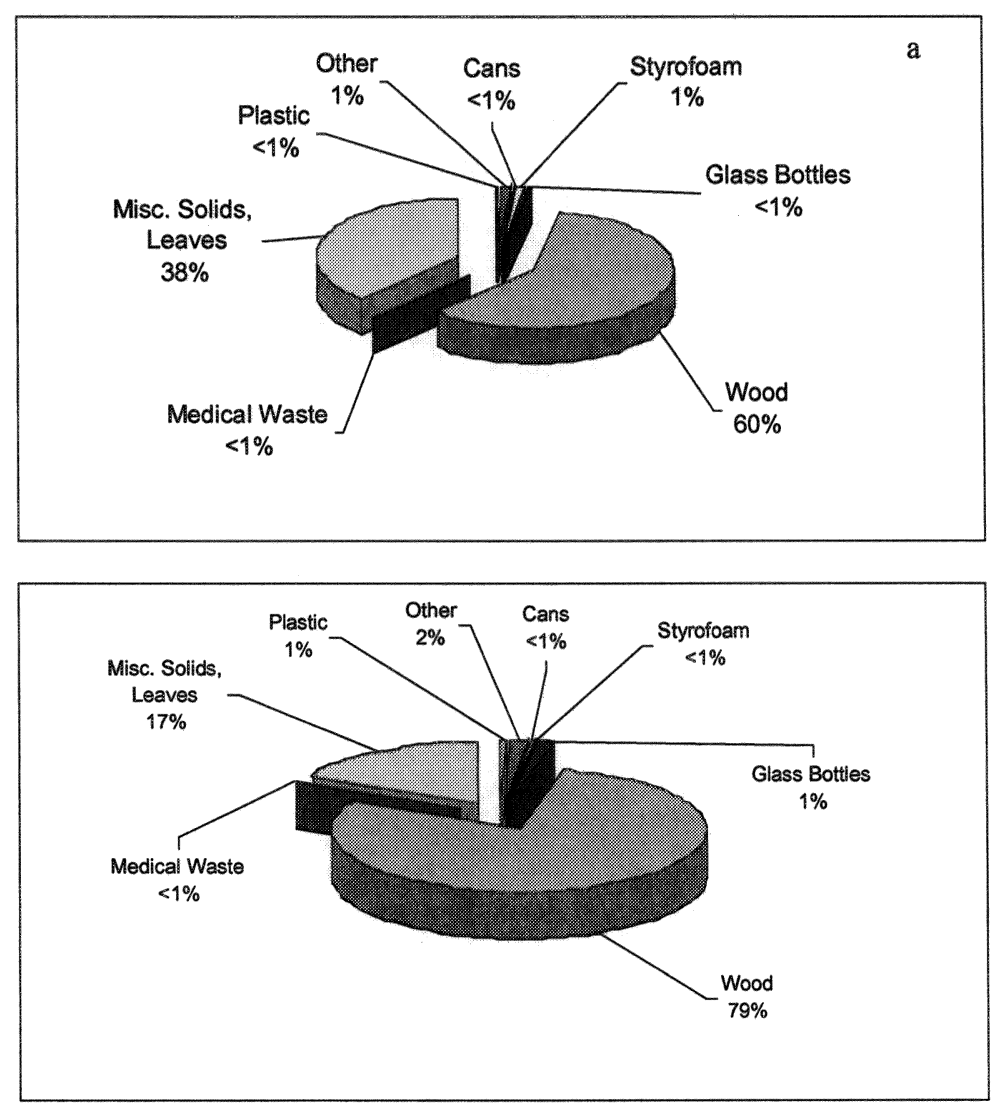

Figure 10.4 Distribution of floatables, Babcock St. sewershed, expressed on a per cent by volume basis (a); and a per cent by mass basis (b). 
The distribution of floatables by type is summarized for the Babcock St. sewershed in Figure 10.4. This distribution was calculated using both the CSO and dry period data, but the distribution was dominated by the CSO periods. The distribution of floatables by type is shown in Figure 10.5 for the Peddie and Saybrook sewersheds, for comparison. The distributions for the two New Jersey study sites were similar. However, there were some clear differences between the Babcock St. sewershed and New Jersey floatables distributions (Figures 10.4 and 10.5). In particular, there was more wood and less plastic in the Babcock St. floatables composition.
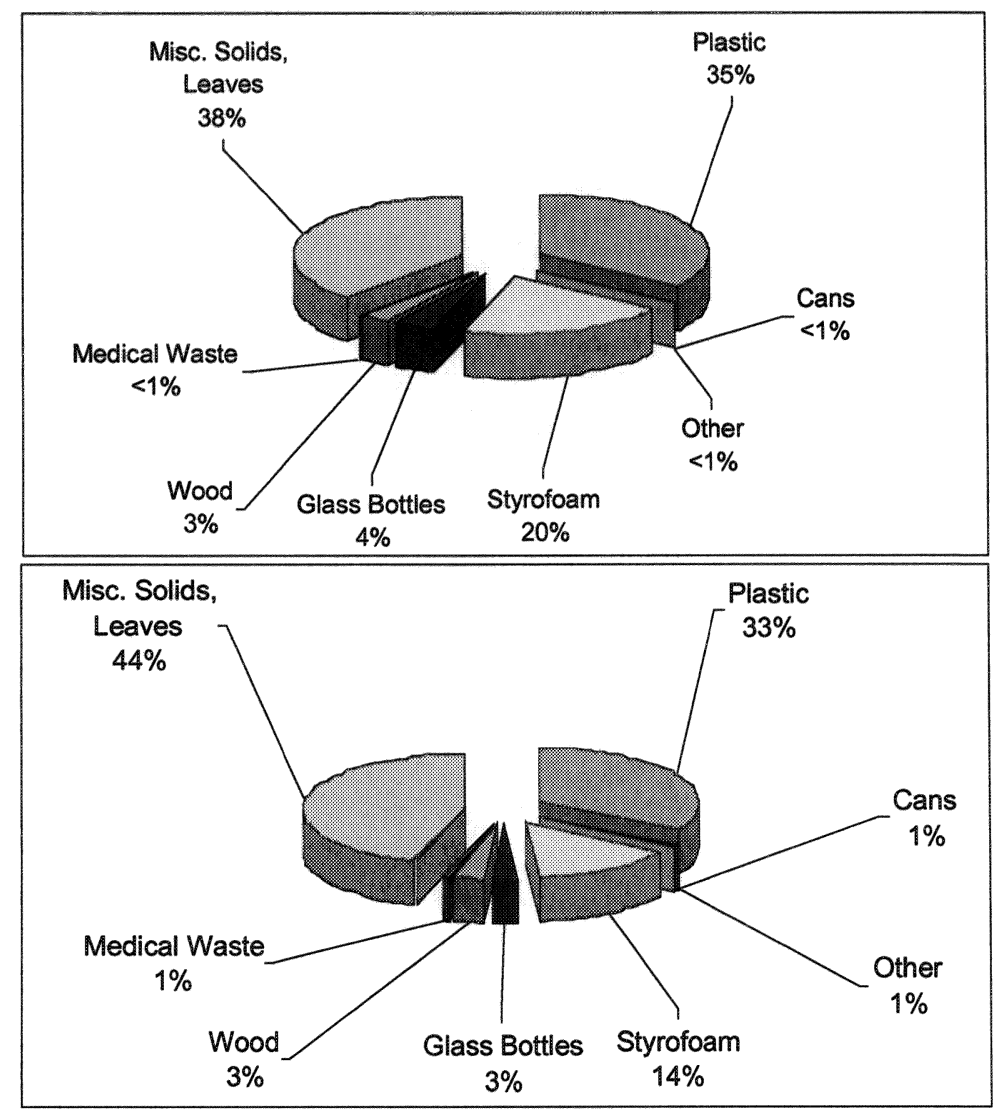

Figure 10.5 Distribution of floatables, expressed on a per cent by volume basis for the Saybrook sewershed, NJ (a); and the Peddie sewershed, NJ (b). Data from Parsons Engineering Science, Inc. (1995). 

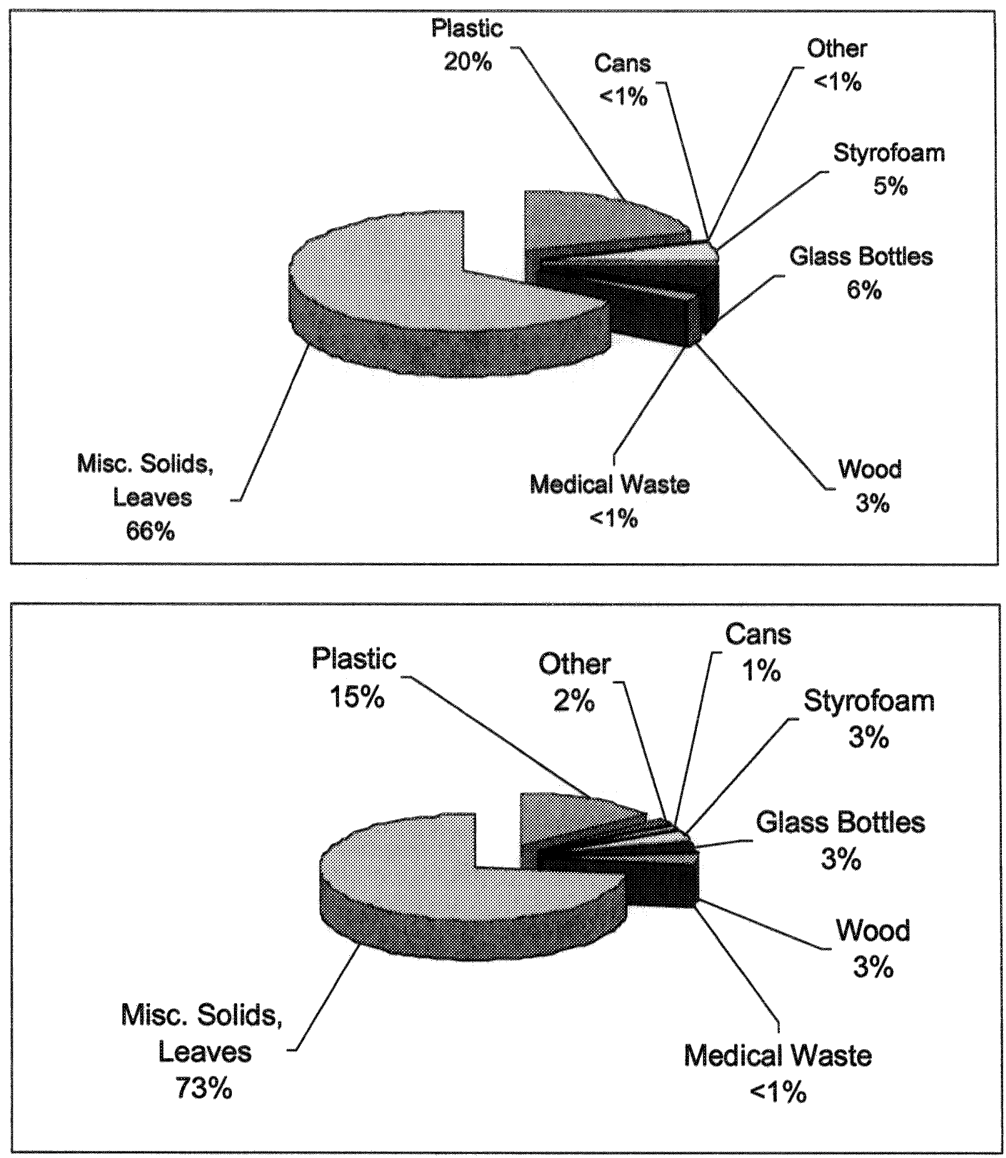

Figure 10.5 (continued) Distribution of floatables, expressed on a per cent by mass basis for the Saybrook sewershed, NJ (a); and the Peddie sewershed, NJ (b). Data from Parsons Engineering Science, Inc. (1995).

\subsubsection{Datasonde Data}

The mean values of all parameters for the two sample sites, on a sample period basis, are shown in Table 10.2. Student's t-tests were applied to determine if there was a significant difference between the average of the mean parameter values for each sample period from the two sites (i.e. a difference between the "mean" values of the second last row in Table 10.2). The Student's t-test results indicated that there was not a significant difference $(\alpha=0.05)$ in the mean values for temperature, conductivity, and dissolved oxygen. The mean value of $\mathrm{pH}$ 
Table 10.2 Datasonde Data, Floatables Project - mean values for each sample period.

\begin{tabular}{|c|c|c|c|c|c|c|c|c|c|c|}
\hline \multirow[b]{2}{*}{ Sample Period } & \multicolumn{5}{|c|}{ Upstream (Bridge) Site } & \multicolumn{5}{|c|}{ CSO Site } \\
\hline & $\begin{array}{c}\text { Temp. } \\
\text { C }\end{array}$ & $\mathrm{pH}$ & $\begin{array}{l}\text { Cond. } \\
\mathrm{mS} / \mathrm{cm}\end{array}$ & $\begin{array}{l}\text { D.O. } \\
\mathrm{mg} / \mathrm{L}\end{array}$ & $\begin{array}{l}\text { Redox, } \\
\text { mV }\end{array}$ & $\begin{array}{c}\text { Temp. } \\
\text { C }\end{array}$ & $\mathrm{pH}$ & $\begin{array}{l}\text { Cond. } \\
\mathrm{mS} / \mathrm{cm}\end{array}$ & $\begin{array}{l}\text { D.O. } \\
\mathrm{mg} / \mathrm{L}\end{array}$ & $\begin{array}{c}\text { Redox, } \\
\text { mV }\end{array}$ \\
\hline 8/13-8/23/99, no CSO & 23.43 & 8.61 & 0.47 & 5.01 & 591.2 & 24.55 & 8.1 & 0.47 & 5.14 & 622.68 \\
\hline 8/23-8/27/99, CSO & 23.03 & 8.52 & 0.51 & 4.09 & 578.72 & 23.02 & 8.05 & 0.46 & 4.9 & 652.03 \\
\hline $8 / 27-8 / 31 / 99$, no CSO & 23.72 & 8.53 & 0.53 & 4.06 & 585.85 & 23.6 & 7.99 & 0.51 & 4.13 & 634.38 \\
\hline 9/3-9/10/99, CSO & 23.65 & 8.58 & 0.47 & 4.57 & 578.56 & 23.78 & 8.13 & 0.46 & 5.39 & 623.96 \\
\hline 9/10-9/17/99, no CSO & 21.91 & 8.78 & 0.49 & 5.13 & 563.25 & 22 & 8.27 & 0.49 & 5.56 & 625.08 \\
\hline 9/17-9/24/99, no CSO & 20.16 & 8.75 & 0.49 & 5.44 & 572.29 & 20.23 & 8.31 & 0.48 & 7.05 & 618.04 \\
\hline 9/24-10/1/99, CSO & 18.94 & 8.8 & 0.49 & 6.02 & 588.23 & 19.28 & 8.38 & 0.48 & 8.33 & 642.21 \\
\hline 10/1-10/7/99, CSO & 15.84 & 8.92 & 0.51 & 6.87 & 586.2 & 16.37 & 8.35 & 0.51 & 8.36 & 625.64 \\
\hline 10/7-10/15/99, CSO & 14.45 & 9.03 & 0.55 & 7.8 & 567.71 & 14.71 & 8.57 & 0.53 & 10.02 & 615.21 \\
\hline 10/15-10/22/99, no CSO & 13 & 9.06 & 0.54 & 7.88 & 605.83 & 13.45 & 8.55 & 0.52 & 9.96 & 626.52 \\
\hline $10 / 22-10 / 29 / 99$, no CSO & 9.6 & 9.36 & 0.59 & 10.21 & 537.8 & 10.19 & 8.75 & 0.58 & 12.66 & 602.87 \\
\hline Mean & 18.88 & 8.81 & 0.51 & 6.10 & 577.79 & 19.20 & 8.31 & 0.50 & 7.41 & 626.24 \\
\hline S.D. & 4.94 & 0.26 & 0.04 & 1.91 & 17.76 & 4.85 & 0.24 & 0.04 & 2.69 & 13.20 \\
\hline
\end{tabular}


was significantly higher $(\alpha=0.05)$ for the Bridge site and the mean value of redox was significantly higher $(\alpha=0.05)$ for the CSO site. This suggests that while the Babcock CSO may have had some impact on the receiving water body quality in terms of conventional parameters, this impact was short-lived and generally filtered out in weekly averaging.

\subsection{Discussion}

\subsubsection{Floatables}

Floatables were successfully collected for five dry weather periods (to evaluate fugitive inputs) and three CSO periods. Floatables accumulation in the trap system was significantly greater during the CSO periods than during the dry weather periods. However, the floatables discharge rate in mass/1000 cubic feet $\left(28.3 \mathrm{~m}^{3}\right)$ of CSO was much lower for the Babcock sewershed as compared to two sewersheds in New Jersey (Figure 10.3). The lower discharge rate may be partly attributed to the use of a larger mesh size in the nylon netting for the Babcock study site $(3 / 4$ inch $(19 \mathrm{~mm})$ vs. $1 / 2$ inch $(12.7$ $\mathrm{mm}$ ) for the New Jersey study), but given the partial clogging of the mesh and the general size of the floatable material, it is believed that the mesh size had relatively little impact. A visual inspection of the Babcock sewer line during several wet weather events qualitatively confirmed that the mass of floatable material was relatively small. The low amount of floatable material may, in part, be the result of the hoods installed on many catchbasins in this part of the city. In a study for New York City, Leo and Kloman (1997; www.hydroqual.com/ papers/wleo/01p wml $01 . \mathrm{htm}$ ) found that hoods reduced floatables loadings by $70 \%$ (based on number of items); $53 \%$ (based on item surface area); and $70 \%$ (based on mass).

Floatables studies in New York City indicated that materials discharging from sewer systems have characteristics similar to street litter and that much of the material found on area shorelines resembled items from CSOs and storm sewers (Newman et al., 1997; www.hydroqual.com/papers/tnewman/01/ p_tln_01.htm). Because a large amount of floatables material in New York Harbor is derived from CSOs and storm sewers, Newman et al. (1997; www.hydroqual.com/papers/tnewman/01/p_tln_01.htm) examined the effect of street sweeping as a floatables control technology. It was reported that routine mechanical sweeping, combined with more intensive manual sweeping, could effectively reduce floatable material on the street and thus be a source control. The cost of this measure was greater than other technologies, but in some cases (e.g. in a high density, commercial urban area) could provide some 
flexibility in meeting CSO abatement goals. In contrast, a large amount of the floatable material in the Buffalo River that is associated with storm events and which can be observed accumulating in shoreline pockets appears to be wood from the upper (rural and suburban) watershed.

Qualitatively, it appeared that CSO events with larger flow volumes produced a greater mass and volume of floatable material (e.g. the CSO event of 11/2/99), although with a small data set we could not rigorously evaluate this observation. On the other hand, data from the New Jersey study (Parsons Engineering Science, Inc., 1995) indicated that there was no significant relationship $(\mathrm{p}=0.05)$ between overflow volume and floatable mass.

The metal frame of the trap system became partially submerged during five sample periods and small CSOs were observed for three of these periods. Because of the possibility that floatables could enter from the river or escape from the CSO discharge, floatables data for these periods were not collected. The pilings that anchored the metal frame were installed as perpendicular as possible using the hydraulic system of a front end excavator from the shoreline (and guided by a Boston Whaler in the water). Given the depth of water and the height of the excavator above the waterline during installation, it is possible that the pilings were not absolutely vertical. Furthermore, the pilings appeared to shift slightly and develop a lean through the course of the study. While this was a fairly difficult site for installation, in the future the trap system should be modified either to use smaller diameter pilings or larger collars to accommodate piling shift.

\subsubsection{Datasondes}

Continuous monitoring of $\mathrm{pH}$, conductivity, temperature, and redox at the CSO and upstream control (Bridge) sites produced values within an expected range. The $\mathrm{pH}$ at both sites may be slightly higher than has been recorded in past studies (e.g. Pettibone and Irvine, 1994), although the values were not unreasonable.

The daily mean flow entering the top of the Buffalo River was calculated as the sum of the daily mean flows measured at the USGS gauge stations on the three major tributaries to the river and adjusted for ungauged area as described by Meredith and Rumer (1987). A small storm event, with a peak of $351 \mathrm{cfs}$ $\left(9.94 \mathrm{~m}^{3} \mathrm{~s}^{-1}\right)$, occurred on $8 / 20-8 / 22 / 99$ and a second small storm event, peak of $402 \mathrm{cfs}\left(11.4 \mathrm{~m}^{3} \mathrm{~s}^{-1}\right)$, was observed between $9 / 7 / 99$ and $9 / 10 / 99$. The mean level of all parameters measured at the CSO site for both the storm events and comparative dry weather periods are shown in Table 10.3. The dry weather comparison periods were taken as the antecedent 72 hour dry periods. The results show that conductivity and dissolved oxygen, in particular, were lower on average for storm events, as compared to dry weather periods. It appears that the lower conductivity was related to a dilution effect. Constituents from 
Table 10.3 Mean values from the Babcock Outfall Hydrolab for storm event, $\mathrm{CSO}$, and dry weather periods.

\begin{tabular}{|c|c|c|c|c|c|c|}
\hline Sample Period & $\begin{array}{l}\text { Sample } \\
\text { Condition }\end{array}$ & Temp. C & $\mathrm{pH}$ & $\begin{array}{l}\text { Cond. } \\
\mathrm{mS} / \mathrm{cm}\end{array}$ & $\begin{array}{l}\text { D.O. } \\
\mathrm{mg} / \mathrm{L}\end{array}$ & $\begin{array}{l}\text { Redox, } \\
\text { mV }\end{array}$ \\
\hline $\begin{array}{l}8 / 20-8 / 22 \text { (storm); } \\
8 / 17-8 / 19 \text { (dry) }\end{array}$ & Storm & 22.0 & 8.05 & 0.451 & 4.51 & 655.5 \\
\hline $\begin{array}{l}8 / 20-8 / 22 \text { (storm); } \\
8 / 17-8 / 19 \text { (dry) }\end{array}$ & $\mathrm{CSO}$ & - & -- & - & -- & -- \\
\hline $\begin{array}{l}\text { 8/20-8/22 (storm); } \\
8 / 17-8 / 19 \text { (dry) }\end{array}$ & Dry & 24.6 & 8.15 & 0.481 & 5.43 & 643.0 \\
\hline $\begin{array}{l}\text { 9/7-9/10 (storm); } \\
\text { 9/7 (CSO); } \\
\text { 9/4-9/6 (dry) }\end{array}$ & Storm & 23.1 & 8.11 & 0.449 & 5.12 & 655.9 \\
\hline $\begin{array}{l}\text { 9/7-9/10 (storm); } \\
\text { 9/7 (CSO); } \\
\text { 9/4-9/6 (dry) }\end{array}$ & $\mathrm{CSO}$ & 23.5 & 8.2 & 0.414 & 6.18 & 524.4 \\
\hline $\begin{array}{l}\text { 9/7-9/10 (storm); } \\
\text { 9/7 (CSO); } \\
\text { 9/4-9/6 (dry) }\end{array}$ & Dry & 24.3 & 8.18 & 0.482 & 5.70 & 602.0 \\
\hline
\end{tabular}

Storm - represents data for the basin-wide runoff event, excluding CSO periods;

$\mathrm{CSO}$ - represents data in the river during a CSO event;

Dry - represents data in the river during an antecedent dry period

chemical weathering of soils and bedrock may predominantly enter rivers in temperate, humid climates via groundwater inputs (Morisawa, 1968; Marsh, 1987). As such, conductivity and dissolved solids concentrations would be greater during baseflow conditions when the principal hydrologic input is groundwater and may become diluted with stormwater runoff (Walling and Webb, 1980). Irvine (2001) reported similar dilution patterns for other locations on the Buffalo River.

New York Water Quality Regulations (Title 6, Chapter X, Parts 700-705) for dissolved oxygen (DO) in $\mathrm{C}$ class, nontrout waters, state "...the minimum daily average shall not be less than $5.0 \mathrm{mg} / \mathrm{L}$, and at no time shall the DO concentration be less than $4.0 \mathrm{mg} / \mathrm{L}$." The mean dissolved oxygen levels for approximately a two week period towards the end of August and into early September were less than $5.0 \mathrm{mg} / \mathrm{L}$ at both Datasonde sites. However, for the sample periods $8 / 23-8 / 27$ and $8 / 27-8 / 31$, it was observed that navigational dredging was being conducted within the stretch of river adjacent to the Datasonde sites. The river during this time was observed to be highly turbid due to sediment resuspension principally associated with the dredging operations (as opposed to the small storm event of $8 / 20-8 / 22$ ) and it appears that sediment oxygen demand negatively affected dissolved oxygen levels, particularly from 8/25-8/27/99 (Figure 10.6). 

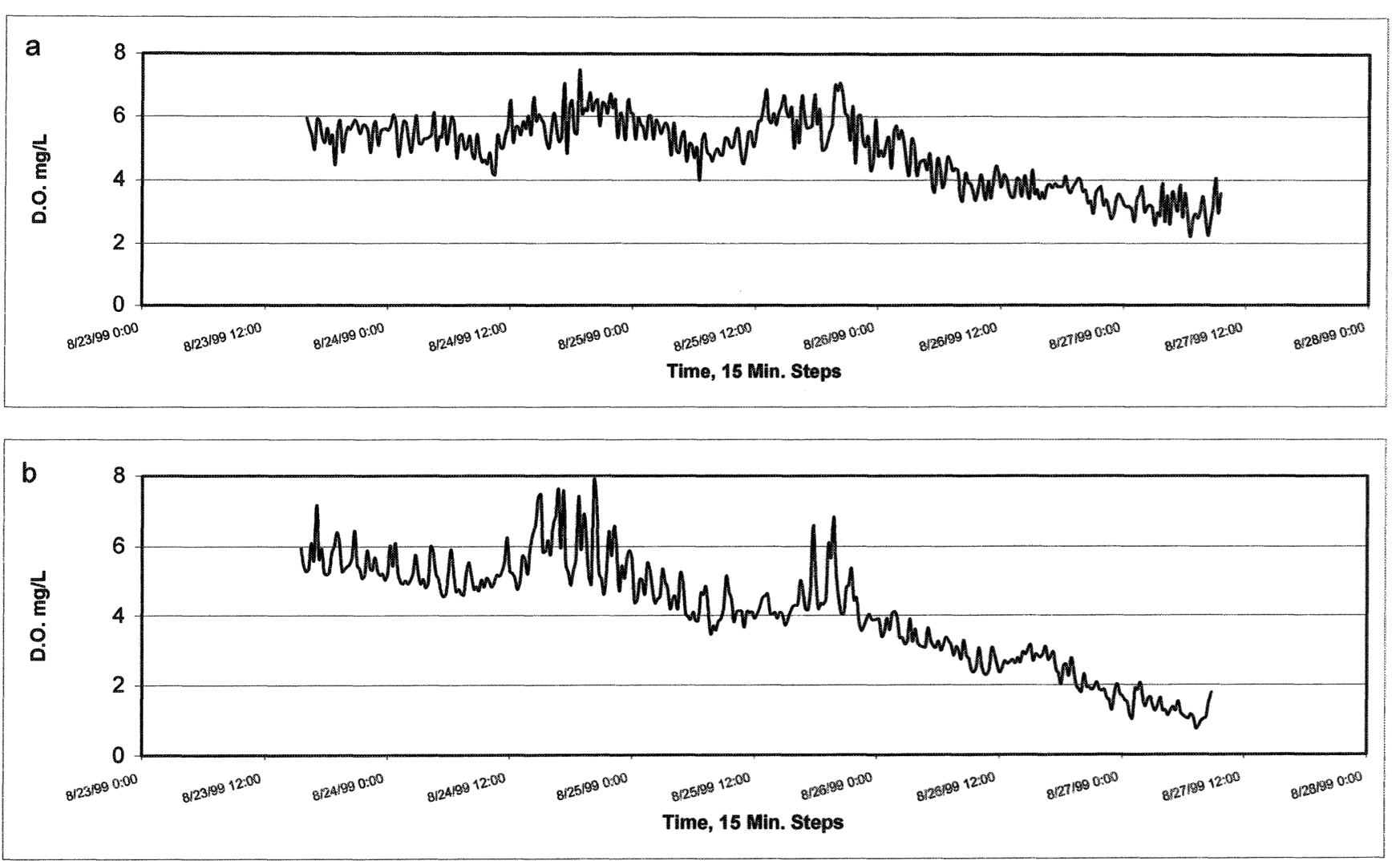

Figure 10.6 Dissolved oxygen levels measured by the Datasondes at the CSO site (a) and the upstream bridge site (b), 8/23-8/27/99. 
It has been observed that CSO discharges can produce a dissolved oxygen sag in a receiving water body (e.g. Freedman and Marr, 1990). The CSO event of 9/7/99 was the largest and most well-defined event recorded during the study period. The event had a total duration of 2 hours 45 minutes, with a total overflow volume of 122,000 cubic feet $\left(3,455 \mathrm{~m}^{3}\right)$, and a peak overflow rate of $19 \mathrm{cfs}\left(0.54 \mathrm{~m}^{3} \mathrm{~s}^{-1}\right)$. While the total duration of the event was 2 hours 45 minutes, overflow occurred between 1:45 to 2:45 a.m. and again between 3:35 and 5:15 a.m. Although there were some minor sags in dissolved oxygen at the CSO site during the overflow event, there also were periods when the dissolved oxygen increased (Figure 10.7). The mean level of dissolved oxygen for the CSO period, as well as the remaining, basin-wide runoff period, and a dry weather comparison period are shown in Table 10.3. On average, dissolved

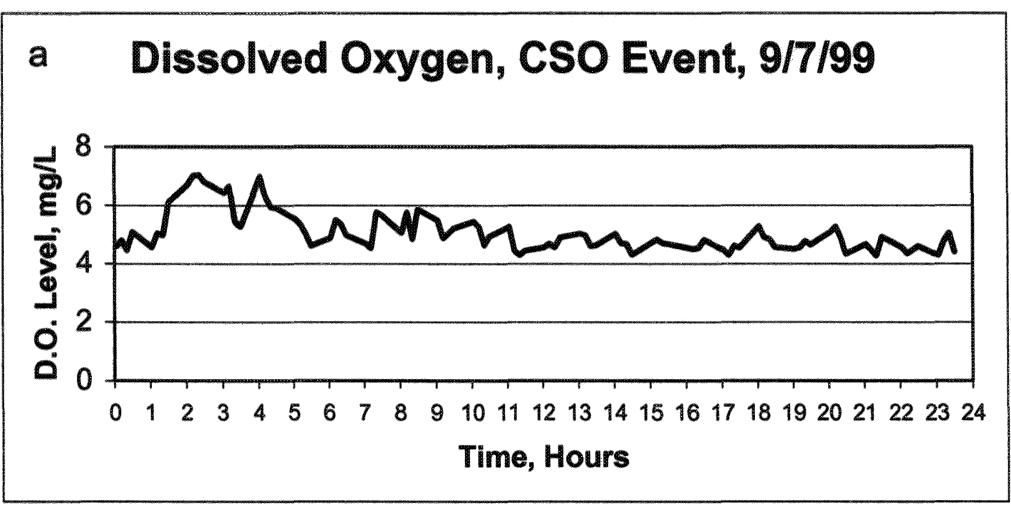

\section{b Dissolved Oxygen 9/7/99, Control Site}

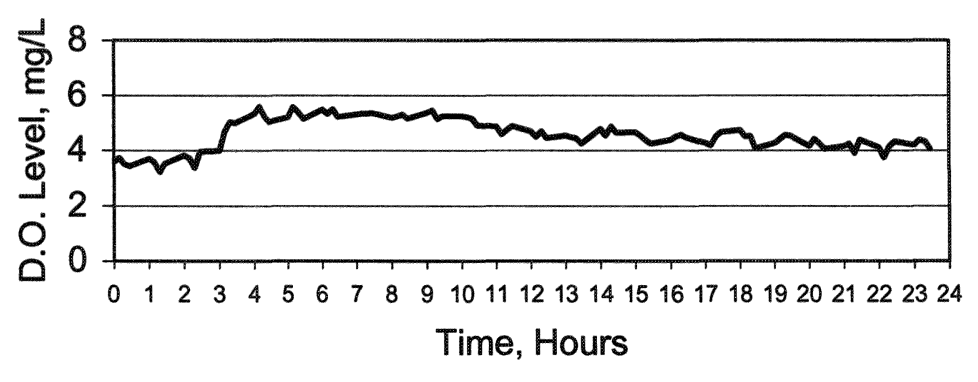

Figure 10.7 Dissolved oxygen levels measured by the Hydrolabs during and after the CSO event of 9/7/99 at the CSO site (a) and the upstream bridge site(b). 
oxygen was higher for the CSO period than either the remaining portion of the runoff event or the dry weather period. The stormwater to sanitary flow ratio is quite high for the Babcock St. sewershed during CSOs and industrial effluents are the major source of sanitary flow (Irvine et al., 1993). For example, Irvine (1999) found that daily mean sanitary flow was in the range of $0.68-1.30 \mathrm{cfs}$ $\left(0.019-0.037 \mathrm{~m}^{3} \mathrm{~s}^{-1}\right)$. Overflow peaks often are in the range of $14-24 \mathrm{cfs}(0.4-$ $0.68 \mathrm{~m}^{3} \mathrm{~s}^{-1}$ ) (Irvine et al., 1993; Irvine, 1999). It is possible that the turbulent combined flow discharging to the receiving water body has a relatively high oxygen level and therefore dissolved oxygen sags do not often occur in the river at the Babcock St. CSO. Irvine (2001) reported a similar dissolved oxygen relationship for another major outfall to the Buffalo River, but dissolved oxygen sags were observed for an outfall to the Black Rock Canal (adjacent to the Niagara River).

\subsubsection{Costs of Floatables Trap System}

The cost of engineering, procurement, installation, and operation and maintenance (O\&M) of the trap system in this study was approximately US $\$ 38,000$. The effort to maintain this type of trap system in the Buffalo River could be considerable. Many of the outfalls along the river are not easily accessible from land and a boat therefore would have to be used to clean the traps after CSO events. Furthermore, the traps would have to be removed each winter and reinstalled in the spring due to ice conditions in the river. The installation at some sites might have to be done using a barge with a pile driver. In comparison, the capital costs for larger trap systems in New Jersey were US $\$ 140,000-\$ 205,000$ with O\&M costs per CSO event being US\$473-\$826 (Parsons Engineering Science, Inc., 1995).

\subsection{Conclusion}

Floatables were collected in an end-of-pipe trap system for dry weather and CSO periods through the late summer and fall, 1999, at a test sewershed that discharges to the Buffalo River, NY. The floatables were sorted into nine categories and the number, mass, and volume in each category were determined. Mean floatable accumulation rates were significantly greater for CSO periods than dry weather periods. The distribution of floatables, by category, in the sampled CSOs for the Buffalo sewershed was compared to the distribution for two sewersheds from a study conducted in New Jersey. The distributions for the two New Jersey sewersheds were similar to each other, but the Buffalo sewershed floatables consisted of more wood and less plastic. 
The mass of floatables trapped per 1000 cubic feet $\left(28.3 \mathrm{~m}^{3}\right)$ of CSO discharge for the Buffalo sewershed also was considerably less than the two sewersheds in New Jersey. The relatively low mass of floatables material discharging from the Buffalo sewershed, in part, may be due to hoods installed on the catchbasins in this part of the city. A large amount of the floatable material in the Buffalo River that is associated with storm events and which can be observed accumulating in shoreline pockets appears to be wood from the upper watershed (rural and suburban land use). The effort to maintain this type of trap system in the Buffalo River would be considerable and alternative floatables control practices should be considered.

The Datasondes provided useful insights to receiving water body quality dynamics. Of greatest interest were the results for dissolved oxygen. Classically described dissolved oxygen sags were not observed in the river at the mouth of the outfall during CSO events. In fact, the greatest decreases in dissolved oxygen levels were observed in association with navigational dredging activities, likely due to sediment oxygen demand when sediment was resuspended.

\section{Acknowledgments}

Funding for this project was provided by the Buffalo Sewer Authority. Thanks to Dan Bentavogli and Jim Caruso of the Sewer Authority for their support of the project. Thanks also to Mike Goehle and Mike Greer for their assistance in the field and laboratory. Comments from two anonymous reviewers were greatly appreciated.

\section{References}

Cigana, J., Couture, M., Meunier, C., and Comeau, Y. 1999. Determination of the vertical velocity distribution of floatables in CSOs. Wat. Sci. Tech., 39(2): 69-73.

Cigana, J.F., Lefebvre, G., Marche, C., and Couture, M. 2000. Experimental capture efficiency of floatables using underflow baffles. Proceedings, Collection System Wet Weather Pollution Control Conference, Rochester, NY, Water Environment Federation, Electronic Media, CD0033WW.

Couture, M., Cigana, J., and Lauzon, M. 2001. Static Overflow Screens to the Rescue of Seldom Activating CSO's. Paper presented at the New England Water Environment Association Annual Conference, Boston, MA, Jan. 30-Feb. 2.

Freedman, P.L. and Marr, J.K. 1990. Receiving-Water Impacts. Control and Treatment of Combined-Sewer Overflows, P.E. Moffa, ed., Van Nostrand Reinhold, NY, pp. 79-117. 
Irvine, K.N. 2001. Continuous Monitoring of Conventional Parameters in the Buffalo River, Harbor, and Black Rock Canal - A Preliminary Assessment. Report to URS Greiner Woodward Clyde, 84p.

Irvine, K.N. 1999. Sewer and Industrial Effluent Sampling in Support of the Buffalo River Combined Sewer Overflow Pollution Prevention Project. Report to the Erie County Department of Environment and Planning, 41p.

Irvine, K., B.G. Loganathan, E. Pratt and H.C. Sikka. 1993. "Calibration of PCSWMM to Estimate Metals, PCBs and HCB in CSOs from an Industrial Sewershed." Journal of Water Management Modeling R175-10. doi: 10.14796/JWMM.R175-10.

Leo, W.M. and Kloman, L. 1997. Use of catch basins to control floatables in New York City. Wet Weather, 1(4); and reproduced on www.hydroqual.com/papers/wleo/ 01/p_wml_01.htm.

Loganathan, B.G., Irvine, K.N., Kannan, K., Pragatheeswarn, V., and Sajwan, K.S. 1997. Distribution of selected PCB congeners in the Babcock Street Sewer District: A multimedia approach to identify PCB sources in combined sewer overflows (CSOs) discharging to the Buffalo River, New York. Archives of Environmental Contamination and Toxicology, 33:130-140.

Marsh, W.M. 1987. Earthscape A Physical Geography, John Wiley and Sons, New York, 510p.

Meredith, D.D. and Rumer, R.R. 1987. Sediment Dynamics in the Buffalo River. Report, Department of Civil Engineering, University at Buffalo, 171p.

Morisawa, M. 1968. Streams Their Dynamics and Morphology, McGraw-Hill Book Company, New York, 175p.

New York State Water Quality Regulations can be accessed at: www.dec.state.ny.us/ website/regs/

Newman, T. 2001. "A Methodology to Design and/or Assess Baffles for Floatables Control." Journal of Water Management Modeling R207-04. doi: 10.14796/JWMM.R207-04.

Newman, T.L., Leo, W.M., Mueller, J.A., and Gaffoglio, R. 1997. Effectiveness of street sweeping for floatables control. Watershed and Wet Weather Technical Bulletin, Water Environment Federation; and reproduced on www.hydroqual.com/ papers/tnewman $/ 01 / \mathrm{p}$ tln 01 .htm.

Newman, T.L., Leo, W.M., and Gaffoglio, R. 2000. Characterization of urban-source floatables. Proceedings, Collection System Wet Weather Pollution Control Conference, Rochester, NY, Water Environment Federation, Electronic Media, CD0033WW.

Parsons Engineering Science, Inc., 1995. CSO Floatable Control Demonstration Project. Final Report to the City of Newark.

Pettibone, G.W. and Irvine, K.N. 1994. Levels and Sources of Indicator Bacteria Associated with the Buffalo River Area of Concern. Report to the U.S. Environmental Protection Agency, Great Lakes National Program Office, 118p.

Shenman, L. undated. Removing Floating Debris from the World's Waterways. www.trashskimmer.com/tp_porttech.htm. 
Sikka, H.C. 1992. Field and Laboratory and Support Results Buffalo River Mass Balance Project. Report to the U.S. EPA, Great Lakes National Program Office, 298p.

U.S. EPA, 1995. Combined Sewer Overflows - Guidance for Nine Minimum Controls. EPA Report EPA 832-B-95-003.

Walling, D.E. and Webb, B.W. 1980. The spatial dimension in the interpretation of stream solute behaviour. Journal of Hydrology, 47: 129-149.

Water Environment Federation, 1994. Combined Sewer Overflow (CSO) Control Policy, Final Policy (40 CFR Part 122), WEF, Alexandria, VA.

Water Environment Federation, 1995. Combined Sewer Overflows Guidance for Nine Minimum Controls, WEF, Report P15126, Alexandria, VA. 